Situs Jurnal : $\underline{\text { http://ejournal.stiepancasetia.ac.id/index.php/jieb }}$

Jilid 6 Nomor 2 Juli 2020

Hal 202 - 209

\title{
APLIKASI SISTEM INFORMASI AKUNTANSI PENJUALAN KREDIT PADA CV. RAJAWALI CITRA MANDIRI
}

\author{
Suwandi*, Lena Magdalena*, Amroni*, Alfi Fauziah*
}

\begin{abstract}
Abstrak : CV. Rajawali Citra Mandiri adalah perusahaan yang begerak di bidang furniture beralamat di Jl. Ciremai Raya Blok D12 Perumnas, Cirebon - Jawa Barat. CV. Rajawali Citra Mandiri saat ini menghadapi permasalahan dalam pengolahan data penjualan kredit dan stok barang, karena masih menggunakan pencatatan transaksi secara manual sehingga dari sisi keamanan dan ketelitian kurang terjamin. Penelitian ini bertujuan untuk memudahkan manajemen CV. Rajawali Citra Mandiri dalam mengolah data penjualan kredit dan stok barang. Pembuatan aplikasi ini menggunakan PHP dan MySQL. Proses penelitian yang dilakukan dengan mencari data-data dengan observasi dan wawancara. Tahap pembuatan aplikasi ini yaitu analisa kelemahan sistem lama, pencarian data, perancangan, pembuatan, pengetesan, dan implementasi dari sistem informasi penjualan kredit dengan PHP dan MySQL. Hasil akhir aplikasi yang telah dibuat berupa laporan barang dan laporan penjualan kredit, yang berisi data transaksi penjualan kredit dan pengeluaran secara keseluruhan. Metode penelitian yang digunakan dalam penelitian ini adalah metode deskriptif dengan studi kasus, tahapan yang dilakukan adalah observasi dan wawancara. Untuk menginput data yang diperlukan selanjutnya dilakukan analisis dan perancangan sistem menggunakan tools Flowchart, Diagram konteks, DFD, dan ERD. Bahasa pemograman adalah PHP Hypertext Preprocessor sedangkan databasenya menggunakan localhost. Hasil dari penelitian ini adalah sebuah sistem infromasi akuntansi untuk penerimaan kas atas penjualan kredit yang terdiri dari fungsi untuk menangani prosedur-prosedur yaitu prosedur penjualan kredit, prosedur pembayaran angsuran, prosedur pembuatan laporan realisasi penjualan kredit, prosedur penerimaan kas dari pembayaran angsuran, dan prosedur pencatatan akuntansi.
\end{abstract}

Kata Kunci : Sistem Informasi Akuntansi, Penjualan Kredit, PHP, MySQL.

* Universitas Catur Insan Cendekia (CIC) Cirebon

Jl. Kesambi 202, Kota Cirebon, Jawa Barat. Telp (0231) 220350

e-mail: suwandi@cic.ac.id 


\section{PENDAHULUAN}

Perkembangan teknologi yang semakin pesat saat ini, mengharuskan perusahaan dituntut untuk dapat menggunakan dan memanfaatkan teknologi dengan sebaik-baiknya. Untuk mendukung proses kerja dibutuhkan kemajuan di bidang teknologi, sehingga dapat diselesaikan secara tepat waktu. Salah satu cara yang dilakukan oleh perusahaan untuk meningkatakan penjualan adalah dengan melakukan penjualan secara kredit. Penjualan kredit dilakukan perusahaan dengan cara mengirimkan barang sesuai dengan pesanan dari pembeli, dan untuk jangka waktu tertentu perusahaan mempunyai tagihan kepada pembeli tersebut. Untuk menghindari tidak tertagihnya piutang, perlu dilakukannya analisis kredit terhadap calon konsumen atau pelanggan yang akan melakukan pembelian secara kredit.

CV Rajawali Citra Mandiri perusahaan yang bergerak dibidang furniture secara tunai dan kredit. Perusahaan ini dirintis pertama kali pada tahun 1997 oleh bapak M.Sihombing, S.H. yang beralamat Jl. Ciremai Raya Blok D12 Perumnas Cirebon. Perusahaan ini menjual berbagai jenis barang seperti meubel, elektronik, springbad dan berbagai jenis keperluan rumah tangga seperti kursi, meja, lemari, tv dan lain-lain secara tunai dan kredit. Akan tetapi penjualannya lebih dominan ke penjualan kredit karena lebih diminati oleh masyarakat luas dengan uang muka 30\% dari harga. Untuk memperluas penjualan perusahaan telah memiliki anak cabang di Kuningan dan Majalengka yang di bawahi oleh supervisor di setiap anak cabang. Dengan penjualan yang sudah masuk sebagian wilayah tiga Cirebon CV. Rajawali Citra Mandiri membutuhkan suatu sistem penjualan kredit.

Saat ini CV. Rajawali Citra Mandiri seluruh data mengenai proses pengolahan data pembayaran kredit masih menggunakan sistem yang belum terkomputerisasi, menghitung pembayaran kredit dengan kalkulator dan pencatatan data masih menggunakan buku lalu disimpan disebuah lemari. Dengan adanya sistem seperti ini, maka informasi yang dihasilkan menjadi kurang akurat dan adanya risiko kesalahan dalam penghitungan pembayaran cicilan dan risiko kesalahan pembayaran yang di timbulkan oleh konsumen. Misalnya pada suatu ketika konsumen datang dan kuitansinya hilang dan konsumen tersebut mengaku telah membayar 3 kali padahal baru 2 kali pembayaran, saat bersamaan data di perusahaan juga hilang sehingga dapat merugikan perusahaan. Selain itu, teknik pengarsipan yang kurang tepat, dokumen pencatatan akuntansi belum disusun dalam dokumen rangkap sehingga dokumen mudah hilang. Oleh sebab itu, peranan aplikasi pencatatan penjualan kredit sangat penting dalam menjalankan kegiatan operasional perusahaan.

Berdasarkan uraian di atas, penyusun merasa tertarik untuk merancang dan mendesain sistem infomasi pencatatan penjualan kredit pada perusahaan sebagai bahan penelitian dengan judul :

"Aplikasi Sistem Informasi Akuntansi Penjualan Kredit (Studi Kasus : CV. Rajawali Citra Mandiri - Cirebon)”.

\section{METODE PENELITIAN Jenis penelitian}

Menurut Nawawi dalam bukunya yang berjudul Manajemen Sumber Daya Manusia Untuk Bisnis Yang Kompetitif tahun 2003. Jenis penelitian ini adalah deskriptif dengan pendekatan studi kasus. Penelitian deskriptif dapat diartikan sebagai pemecahan masalah yang diselidiki dengan melukisan keadaan subyek dan obyek penelitian pada saat sekarang berdasarkan fakta-fakta yang tampak. Data studi kasus di peroleh dari semua pihak yang bersangkutan. Sebagai sebuah studi kasus maka data yang dikumpulkan berasal dari berbagai sumber dan penelitian ini hanya berlaku pada kasus yang diselidiki. Metode studi kasus sebagai salah satu pendekatan deskriptif adalah penelitian yang di lakukuan secara intensif, terperinci, dan mendalam terhadap organisme, lembaga atau gejala tertentu dengan daerah atau subyek yang sempit. 
Pelaksanaan dan penelitian deskriptif tidak terbatas sampai pada pengkumpulkan dan penyusunan data, tetapi meliputi analisis dan interpretasi tentang data selain itu yang dikumpulkan memungkinkan menjadi kunci terhadap apa yang diteliti, sehingga memberikan gambaran dan informasi mengenai masalah tersebut.

\section{Tahapan Pengumpulan Data}

Berikut ini beberapa tahapan penelitian yang digunakan dalam pengumpulan data:

Penelitian lapangan : berupa observasi dan wawancara, pertama melalui observasi adalah dengan mengumpulkan bahanbahan yang dilakukan dengan pengamatan dan pencatatan secara sistematis terhadap fenomena-fenomena yang dijadikan objek pengamatan. Dalam hal ini penulis mengamati seluruh aktivitas yang terjadi pada CV. Rajawali Citra Mandiri. Yang kedua dengan melakukan wawancara, dilakukan dengan cara memberikan pertanyaan kepada pemilik atau karyawan CV. Rajawali Citra Mandiri yang berkaitan dengan judul penelitian. Tahap selanjutnya adalah dengan melakukan studi pustaka dengan cara mengumpulkan data, membaca literatur dan buku-buku, serta melakukan pencarian data-data yang diperlukan dalam penelitian ini melalui internet.

\section{Tahapan Penerapan Penelitian}

Pada tahapan penelitian kami mengadopsi metode dalam pengambangan perangkat lunak menggunakan Classic Life Cycle Model. Model ini merupakan model konvensional yang sering disebut Waterfall Model karena tahapan-tahapannya yang sistematis dan berurutan dalam membangun perangkat lunak.

\section{System Engineering (Rekayasa Sistem)}

Pada tahap ini dimulai dengan menentukan kebutuhan untuk seluruh elemen-elemen sistem dan mengalokasikannya untuk perangkat lunak.

\section{Design (Desain)}

Pada tahap ini perancangan suatu sistem digambarkan dengan menguraikan alur sistem sampai alur dokumen yang akan dikembangkan dengan menggunakan tools antara lain: flowchart, flowmap, diagram konteks, ERD (Entity Relationship Diagram) dan database.

\section{Coding (Pengkodean)}

Setelah melakukan perancangan desain, kemudian merubah desain tersebut menjadi bentuk yang dimengerti komputer yaitu dengan memberikan coding atau pengkodean pada perangkat lunak tersebut.

\section{Testing (Uji Coba)}

Setelah tahap pengkodean selesai dan program dapat digunakan, testing atau uji coba dapat dilaksanakan. Testing difokuskan pada logika internal dari perangkat lunak, fungsi eksternal dan mencari segala kemungkinan kesalahan.

\section{Maintenance (Perawatan)}

Program yang telah dibuat dan berjalan dengan baik harus dilakukan proses perawatan agar sistem yang dirancang tetap dapat digunakan dengan baik.

\section{KERANGKA TEORITIS DAN HIPOTESIS}

\section{Pengertian Sistem}

Menurut Andri Kristanto dalam bukunya yang berjudul Perancangan Sistem Informasi dan Aplikasinya tahun 2018. Sistem adalah suatu jaringan kerja dari prosedur-prosedur yang saling berhubungan, berkumpul bersama-sama untuk melakukan suatu kegiatan atau untuk menyelesaikan suatu sasaran yang tertentu.

\section{Pengertian Informasi}

Menurut Raymond dalam bukunya yang berjudul Sistem Informasi Manajemen 1996. "Informasi adalah data yang telah diorganisasi atau data yang telah diproses telah memiliki kegunaan dan manfaat atau data yang telah diproses." 


\section{Pengertian Sistem Akuntansi}

Menurut Mulyadi dalam bukunya yang berjudul Sistem Akuntansi 2017. "Sistem akuntansi adalah organisasi formulir, catatan, dan laporan yang dikoordinasi sedemikian rupa untuk menyediakan informasi keuangan yang dibutuhkan oleh manajemen guna memudahkan pengelolaan perusahaan."

\section{Pengertian Sistem Informasi Akuntansi}

Menurut Krismiaji dalam bukunya yang berjudul Sistem Informasi Akuntansi 2010. Sistem informasi akuntansi adalah sebuah sistem yang memproses data dan transaksi guna menghasilkan informasi yang bermanfaat untuk merencanakan, pengendalian dan mengoprasikan bisnis.

\section{Sistem Penjualan Kredit}

Menurut Mulyadi dalam bukunya yang berjudul Sistem Akuntansi 2017. Transksi penjualan barang atau penyerahan jasa jika order pelanggan telah dipenuhi dengan pengiriman barang atau penyerahan jasa, untuk jangka waktu tertentu perusahaan memiliki piutang kepada pelanggannya. Kegiatan penjualan kredit ini ditangani oleh perusahaan melalui sistem penjualan kredit.

\section{Pengertian Kartu Piutang}

Menurut Mulyadi pada bukunya yang berjudul Sistem Akuntansi 2017. Kartu Piutang merupakan catatan akuntansi yang merupakan buku pembantu yang berisi rincian mutasi piutang perusahaan pada tiap-tiap debiturnya.

\section{Data Flow Diagram (DFD)}

Menurut Menurut Jogiyanto pada yang berjudul Analisa dan Design Sistem Informasi tahun 2010. "Data Flow Diagram (DFD) merupakan alat yang digunakan untuk menggambarkan suatu sistem yang telah ada atau sistem baru yang akan dikembangkan secara logika tanpa mempertimbangkan lingkungan fisik dimana data tersebut mengalir ataupun lingkungan fisik dimana data tersebut akan disimpan."

\section{Entitas Relationship Diagram (E-RD)}

Diagram E-RD secara grafis menggambarkan isi sebuah database. Diagram ini menunjukan berbagai entitas yang terlibat dan pola hubungan antar entitas. Yang dimaksud dengan entitas adalah sebuah obyek yang digunakan untuk mengumpulkan data.

\section{PROPOSISI}

Menurut Tommy L.H. Tumalun dan Sonny Pangerapan, dalam penelitian berjudul "Analisis Sistem Informasi Akuntansi Penjualan Kredit Di PT Nusantara Sakti Cabang Manado" (2019). Sistem informasi akuntansi penjualan kredit pada PT Nusantara Sakti Cabang Manado sudah menggunakan sistem online yang baik yaitu cepat, aman dan murah. Namun terdapat kekurangan dalam penerapan sistem informasi akuntansi penjualan Kredit. Kekurangan tersebut didapat dari beberapa fungsi yang merangkap tugas fungsi tersebut. Fungsi tersebut yaitu fungsi kas dan akuntansi yang dirangkap oleh satu orang. Karena adanya perangkapan tugas maka dapat timbul kecurangan dan pekerjaan yang kurang efektif dan efisien. Terdapat juga kekurangan dari fungsi kredit yang melakukan survei tidak sesuai standar yang ada yaitu meloloskan pemohon kredit dengan cara memanipulasi data pemohon, seperti data slip gaji.

Menurut Erlina dan Moch. Dzulkirom AR, "Analisis Sistem Dan Prosedur Penjualan Dan Penerimaan Kas Dalam Mendukung Pengendalian Intern (Studi Pada PT. Astra International, Tbk Auto 2000 Malang Sutoyo) (2019), Sistem dan prosedur penjualan dan penerimaan kas dalam mendukung pengendalian intern pada PT. Astra International, Tbk AUTO 2000 Malang Sutoyo pada penjualan dan penerimaan kas kendaraan, sparepart serta service sudah dilaksanakan dengan baik. Sistem dan prosedur penjualan kendaraan secara tunai maupun kredit, penjualan sparepart secara tunai maupun kredit serta 
penjualan service sudah dilaksanakan oleh beberapa fungsi yang saling terkait yang sudah melaksanakan tugas dan tanggungjawabnya masing-masing.

Menurut Sorta laura dan Hendra Setiawan (2018), "Penerapan Sistem Informasi Akuntansi Penjualan Dalam Menunjang Efektiivitas Pengendalian Intern Penjualan (Studi Kasus pada PT Indomilk) (2018), Sistem Informasi Akuntansi Penjualan pada PT Indomilk sudah baik karena didukung dengan pengendalian intern yang baik. Hal ini terbukti dengan adanya sistem yang ada dalam perusahaan, yaitu software akuntansi, yang berfungsi untuk mengurangi resiko kesalahan dalam setiap pencatatan. Dapat terlihat juga dari sisi penjualannya, terdapat peningkatan penjualan setiap tahunnya baik dalam penjualan tunai maupun penjualan kredit. Didukung juga dengan keserasian hubungan antar karyawan yang menjadi faktor penentu untuk mendukung sistem yang baik dalam perusahaan PT Indomilk tersebut.

Menurut Wasiatur Rohmah, "Analisa Sistem dan Prosedur Akuntansi Penjualan Kredit untuk Menilai Sistem Pengendalian Intern pada CV.Maju Mapan" (2018), Pengendalian intern yang ada dalam sistem dan prosedur akuntansi penjualan kredit pada CV. Maju Mapan yaitu struktur organisasi yang memisahkan tanggung jawab fungsional secara tegas. Sistemotorisasi dan prosedur pencatatan yang memberikan perlindungan yang cukup terhadap kekayaan perusahaan.

Proposisi 1 : Sistem Informasi Akuntansi Penjualan Kredit mendukung pengendalian intern perusahaan.

Menurut Setiadi Hartoko, "Sistem Informasi Akuntansi Pada Penjualan dan Penerimaan Kas Pada PT. Sumber Purnama Sakti Motor Lamongan” (2019), Penerapan sistem akuntansi penjulaan dan penerimaan kas yang dilakukan oleh PT. Sumber Purnama Sakti Motor secara keseluruhan sudah baik. Hal ini dikarenkana fungsi - fungsi yang terkait dokumen yang digunakan, catatan yang digunakan, informasi yang diperlukan, dan prosedur dari sistem penjualan dan penerimaan kas yang sudah berjalan dengan baik dan memadai.

Menurut Dionisius Aditya Kurniawan, "Evaluasi Sistem Akuntansi Penjualan Kredit (studi kasus PT. Mulford Indonesia, Cabang Jogjakarta) (2018), Sistem Akuntansi penjualan kredit pada PT. Mulford Indonesia Cabang Yogyakarta sudah sesuai dengan teori menurut Mulyadi, hal ini disebabkan karena dalam praktik di lapangan fungsi terkait, informasi yang diperlukan manajemen, dokumen yang digunakan, catatan-catatan akuntansi yang digunakan, jaringan prosedur yang membentuk sistem, dan pengendalian internal telah sesuai dengan teori menurut Mulyadi.

Proposisi 2 : Sistem Informasi Akuntansi Penjualan Kredit sesuai dengan teori Mulyadi.

(Yaitu dalam praktik di lapangan fungsi terkait, informasi yang diperlukan manajemen, dokumen yang digunakan, catatan-catatan akuntansi yang digunakan, jaringan prosedur yang membentuk system).

Menurut Rudi Bratamanggala dan Dwi Wijayanti, “Analisis Sistem Informasi Akuntansi Penjualan dan Pengeluaran Kas terhadap Laba Perusahaan di PT. Batara Mega Krida Kencana” (2018), Penjualan secara parsial berpengaruh dan signifikan terhadap Laba pada perusahaan PT. Batara Mega Krida Kencana Tahun 2012-2016 dengan nilai signifikan sebesar 0.0028 . Persentase $28 \%$ dari hasil penjualan material,sedangkan sisanya yang tidak di teliti sebesar $72 \%$ dengan variabel lain yaitu beban gaji, beban sewa, beban penyusutan, beban pemeliharaan, perjalanan dinas, dll. Adanya pengaruh penjualan terhadap perubahan laba karena tingkat penjualan yang lebih besar dibandingkan dengan biaya usaha.

Proposisi 3: Merujuk pendapatnya Rudi Bratamanggala dan Dwi 
Wijayanti Analisis Sistem Informasi

Akuntansi Penjualan dan Pengeluaran Kas berdampak terhadap Laba Perusahaan.

\section{HASIL DAN PEMBAHASAN}

Analisa Sistem Berjalan

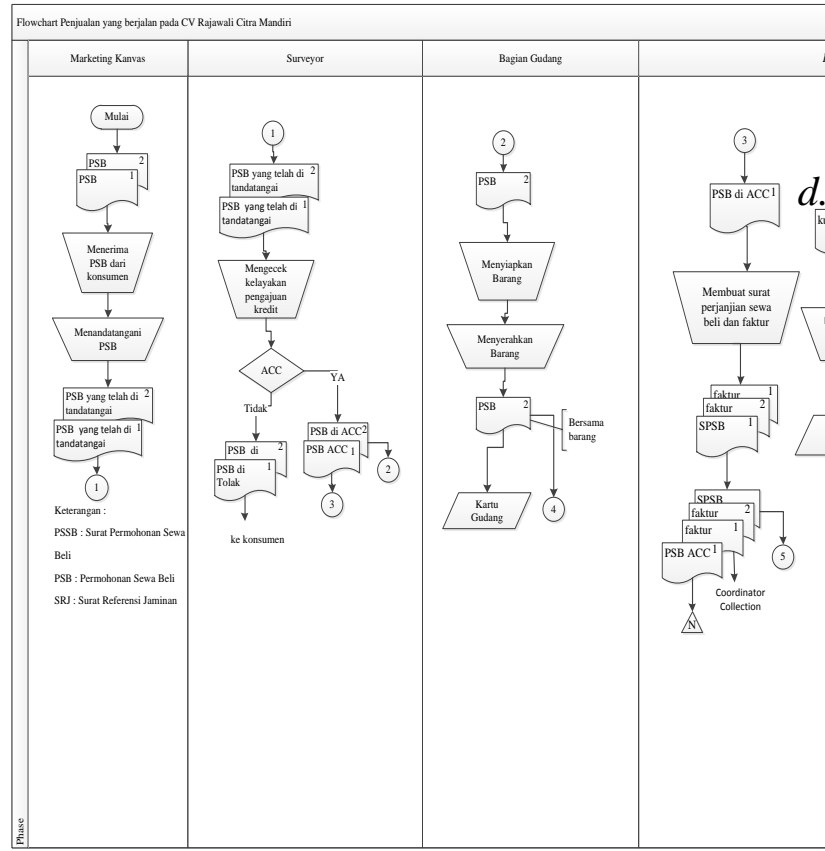

Gambar 1 : Flowchart Manual Penjualan Kredit CV. Rajawali Citra Mandiri

\section{Narasi Flowchart Prosedur Penjualan}

a. Marketing Kanvas

Prosedur ini dimulai pada saat marketing kanvas menerima PSB rangkap dari konsumen sebanyak 2 rangkap dan menandatanganinya, lalu PSB 2 rangkap tersebut diberikan ke bagian surveyor.

b. Bagian Surveyor

Bagian surveyor menerima PSB sebanyak 2 rangkap dari bagian marketing kanvas lalu mengecek kelayakan pengajuan kredit jika ditolak makan PSB 2 rangkap tersebut diberikan ke konsumen, jika di setujui maka
PSB rangkap 1 diberikan ke bagian pembukuan dan rangkap 2 diberikan ke bagian gudang.

c. Bagian Gudang

Bagian gudang menerima PSB rangkap 2 dari bagian surveyor lalu bagian gudang menyiapkan dan menyerahkan barang kemudian PSB rangkap 2 dicatat ke kartu gudang lalu diberikan ke bagian pengiriman bersama barang.

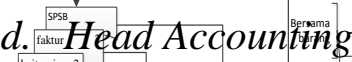

Head Accounting menerima PSB

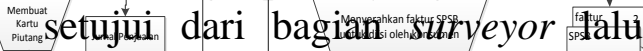
membuat surat perjanjian sewa beli

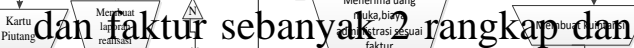
SPSB 1 rangkap, SPSB rangkap 1 diberikan ke bagian 'pengiriman, faktur rangkap 1 dan 2 diberikan ke bagian coordinator collection, SPSB rangkap 1 yang sudah di setujui diarsip berdasarkan nomor.

Pada bagian pembukuan juga menerima SPSB, faktur rangkap 2 dan kuitansi rangkap 2 dari bagian kasir lalu kuitansi rangkap 2 akan dibuat kartu piutang dan dicatat ke kartu piutang, faktur rangkap 2 akan dibuat jurnal penjualan cetak jurnal penjualan dan membuat laporan realisasi penjualan cetak laporan realisasi penjualan yang diberikan ke pemilik, lalu SPSB diarsip berdasarkan nomor dan selesai.

e. Bagian Pengiriman

Bagian pengiriman menerima PSB rangkap 2 bersama barang dari bagian gudang, dan menerima SPSB dan faktur rangkap 2 dari bagian pembukuan lalu menyerahkan faktur SPSB untuk diisi oleh konsumen dan menerima uang muka, biaya administrasi sesuai faktur dan bagian pengiriman juga menerima faktur rangkap 2 dan SPSB rangkap yang diberikan ke konsumen. 
Dari konsumen menerima kelengkapan SPSB dan faktur, dan menerima SPSB dan faktur rangkap 2 lalu membuat kuitansi dan menerima faktur rangkap 2, SPSB, kuitansi rangkap 1 dan 2 dimana faktur rangkap 2 diberikan ke bagian kasir lalu SPSB, kuitansi rangkap 1 dan diberikan ke konsumen.

f. Kasir

Bagian kasir menerima faktur rangkap 2 , SPSB dan kuitansi rangkap 2 dari bagian pengiriman, lalu menerima laporan penerimaan uang muka,biaya administrasi dan memeriksa faktur, SPSb dan kuitansi lalu menerima SPSB, faktur rangkap 2 dan kuitansi rangkap 2 yang diberikan ke bagian pembukuan.

\section{Flowmap Komputerisasi}

Analisa Sistem Berjalan

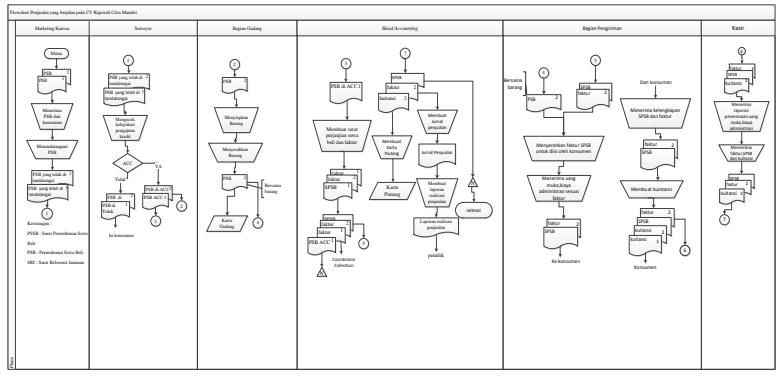

Gambar 1 : Flowchart Manual Penjualan Kredit CV. Rajawali Citra Mandiri

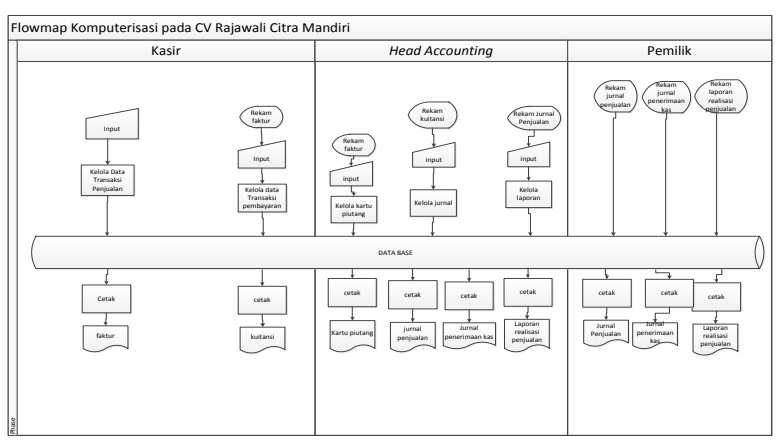

Gambar 2 : Flowmap Komputerisasi Penjualan Kredit

\section{DIAGRAM KONTEKS}

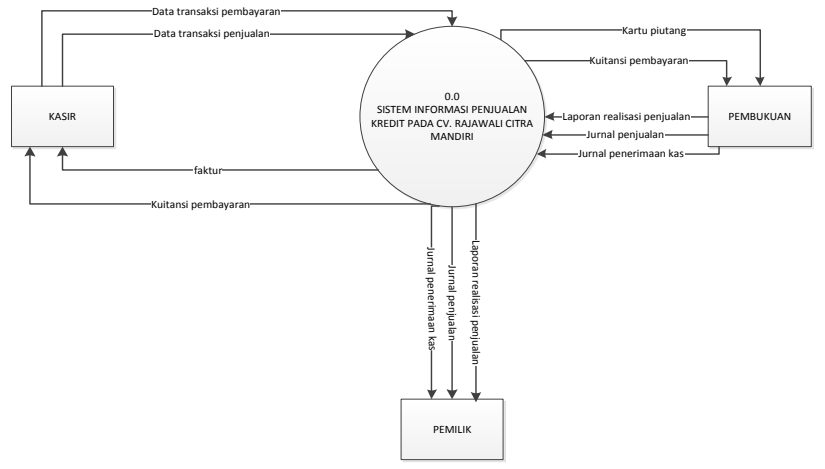

Gambar 3 : Diagram Konteks

\section{Entitas Relationship Diagram (ERD)} Sistem Pencatatan Penjualan Kredit

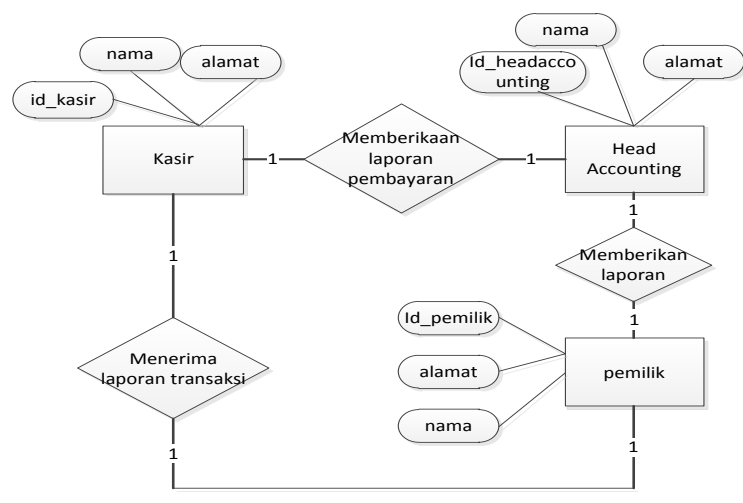

Gambar 4 : Entitas Relationship Diagram Sistem Informasi Akuntansi Penjualan Kredit

Keterangan :

Satu bagian kasir memberikan laporan pembayaran ke satu head accounting, lalu satu head accounting memberikan laporan ke pemilik, dan satu pemilik menerima laporan transaksi dari satu kasir.

\section{Rancangan Input dan Output Rancangan Input}

Desain input merupakan desain form yang terdapat dalam sebuah program Aplikasi Sistem Pencatatan Penjualan Kredit yang berguna sebagai alat bantu untuk menginput data, memproses data dan menjalankan aplikasi tersebut.

\section{Rancangan Output}

Desain output merupakan rancangan desain yang ingin dihasilkan 
dari sebuah program aplikasi sistem informasi akuntansi persediaan bahan baku yang berguna sebagai alat bukti transaksi maupun sebagai laporan untuk manajemen sebagai pertimbangan dalam pengambilan keputusan.

\section{Rancangan Form Menu Bagian Kasir Form Menu Utama}

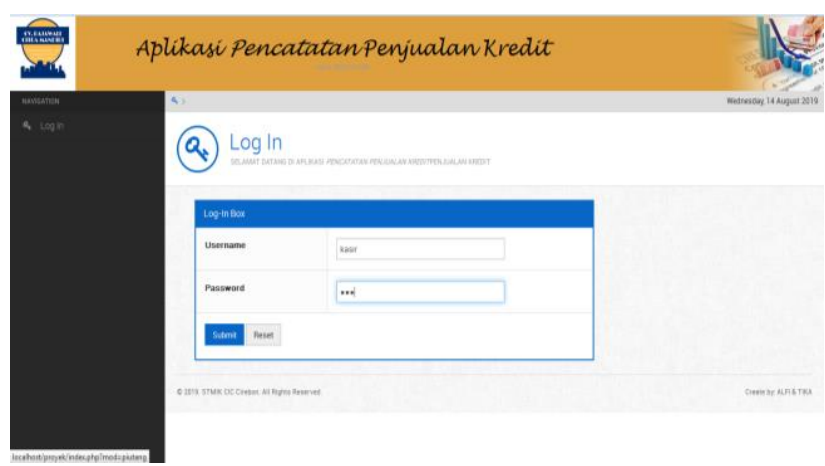

Gambar 5 : Tampilan Login

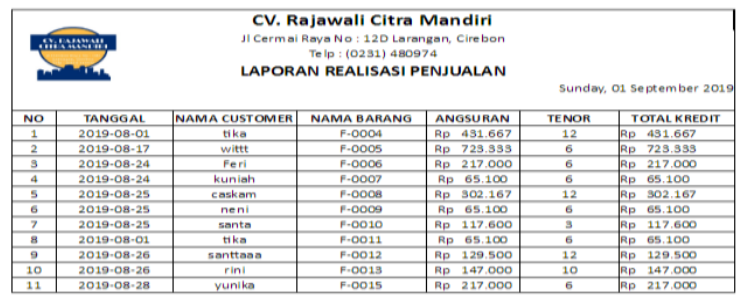

Cirebon, 01 se ptember 2010

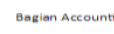

\section{Gambar 6 : Laporan Realisasi Penjualan}

\section{KESIMPULAN}

Berdasarkan uraian di atas, serta hasil observasi dari CV. Rajawali Citra Mandiri maka penulis dapat memberikan kesimpulan bahwa :

1. Rancangan Aplikasi Sistem Informasi Penjualan Kredit berbasis komputer ini mempermudah manajemen $\mathrm{CV}$. Rajawali Citra Mandiri dalam melakukan proses transaksi penjualan kredit dan pembuatan laporan yang dibutuhkan. sehingga dapat meminimalisasi terjadinya kesalahan.

2. Aplikasi ini mempermudah proses pengendalian pada CV. Rajawali Citra
Mandiri khususnya pengendalian penjualan kredit dan piutang.

3. Dengan adanya Aplikasi Sistem Pencatatan Penjualan Kredit pada CV. Rajawali Citra Mandiri laporan realisasi penjualan dan laporan piutang sudah terdata secara up to date.

\section{DAFTAR PUSTAKA}

[1] Ardana, I Cenik. Sistem Informasi Akuntansi, Jakarta. Mitra Wacana Media, 2016.

[2] James. Sistem Informasi Akuntansi, Jakarta: Salemba Empat, 2001.

[3] Jogiyanto. Analisa dan Design Sistem Informasi, Yogyakarta: Andi, 2010.

[4] Krismiaji. Sistem Informasi Akuntansi, Yogyakarta: UPP AMP YKPN, 2010.

[5] Kristanto, Andri. Perancangan Sistem Informasi dan Aplikasi, Yogyakarta: Gava Media, 2018.

[6] Lukman, Hendro. Sistem Informasi Akuntansi, Jakarta: Mitra Wacana Media, 2016.

[7] Mulyadi. Sistem Akuntansi, Jakarta: Salemba Empat, 2017.

[8] Nawawi. Manajemen Sumber Daya Manusia Untuk Bisnis Yang Kompetitif, Yogyakarta: Gadjah Mada University Press, 2003.

[9] Raymond. Sistem Informasi Manajemen, Jakarta: PT Prenhallindo, 1996.

[10] Sidik, Betha. Pemrograman Web dengan PHP 7, Bandung: Informatika, 2017.

[11] Yulica Wardani, Dedi Suhendro, "Sistem Informasi Pemesanan dan Pembayaran Kamar pada Apple Hotel Perdagangan Kabupaten Simalungun", Jurnal Ilmiah MEDIA SISFO vol.14 No.1, pp.54-62, 2020. 